Marta PRZYSZYCHOWSKA

(Warszawa, UKSW)

\title{
KONCEPCJA PODWÓJNEGO STWORZENIA \\ JAKO PRÓBA WYJAŚNIENIA GENEZY \\ ŚWIATA ZMYSŁOWEGO \\ (Filon z Aleksandrii, Orygenes, Grzegorz z Nyssy)
}

Trzeba przyznać, że filozofii starożytnej daleko było do nauki o stworzeniu. Doktryny monistyczne, ze stoicyzmem na czele przyjmowały, ujmując rzecz najogólniej, ze istnieje tylko Bóg, który z konieczności emanuje z siebie świat. I tak stoicy uznawali, że ,początkiem i tworzywem wszystkiego, co istnicje jest boski i inteligentny ogień [...] świat fenomenalny wyłaniał się z twórczego ognia oraz w nim ginąl nieskończoną ilość razy"1. Doktryny dualistyczne najczęściej przyjmowały istnienie odwiecznej materii i Demiurga, który tę materię ukształtowal. Najbardziej rozpowszechnioną nauką o takim charakterze był w starożytności platonizm, według którego Demiurg ukształtował materię wpatrując się w idee ${ }^{2}$. Wielką popularnością cieszyły się także zapatrywania gnostyków, uznające świat za twór upadłej mądrości lub pierwotnego chaosu, a nie najwyższego Boga ${ }^{3}$.

M. Osmański zauważa związek prawdy o stworzeniu z koncepcją bóstwa: „Platoński Demiurg jest jedną z zasad tworzenia, obok materii i idei, które są od niego w swoim istnieniu niezależne. W sensie bytowym wszystkie trzy zasady są więc równorzędne. Tymczasem według koncepcji żydowskiej różnica, która dzieli Boga i świat jest niemal nieskończona, a myślicicl, który wyjaśnia akt stwórczy w języku racjonalnym nie może go wyrazić bez jednoczesnego podkreślania boskiej transcendencji", . Cechy, które M. Osmański przypisal platonizmowi, odnoszą się w równym, a niekiedy i w jeszcze większym stopniu do pozostałych systemów. Podobnie jak platonizm, także nurty gnostyckie uznają istnienie równorzędnych albo przynajmniej porównywalnych dwóch zasad istnienia. Oczywistym jest, że tym bardziej doktryny monistyczne nie potrafią oddzielić Boga od świata.

Czy może zatem istnieć jakikolwiek związek między filozoficzną wizją świata a biblijną koncepcją stworzenia, która podkreśla, że Bóg sam powołuje

'A. Krokiewicz, Zarys filozofii greckiej, Warszawa 2000, 462.

2 Por. Plato, Timajos 29A. 30B.

${ }^{3}$ Por. J.N.D. Kelly, Poczqıki doktryny chrześcijańskiej, tlum. J. Mrukówna, Warszawa 1988, 30.

${ }^{4}$ M. Osmański, Logos i stworzenie. Filozoficzna interpretacja traktatu "De opificio mundi" Filona z Aleksandrii, Lublin 2001, 8. 
wszystko do bytu, nie korzystając z żadnej uprzednio istniejącej materii, ani nie wyprowadzając stworzeń $z$ własnej substancji ${ }^{5}$. Czy możliwe jest przedstawienie takiej nauki o powstaniu świata i człowieka w języku filozoficznym, co więcej, czy jest możliwa jej filozoficzna interpretacja? W niniejszym artykule przyjrzę się trzem próbom takiej właśnie filozoficznej interpretacji biblijnego przekazu. Próby te łączy nie tylko powiązanie $z$ tradycją platońską w szerokim tego slowa znaczeniu 6 , ale także specyficzne owej tradycji wykorzystanie. Nie przypadkowo bowiem zamierzam zająć się $w$ tym artykule naraz Filonem z Aleksandrii, Orygenesem i Grzegorzem z Nyssy. Wszyscy trzej bowiem mówią o podwójnym stworzeniu i choć każdy z nich robi to inaczej, niewątpliwie ich koncepcje mają punkty wspólne.

1. Filon z Aleksandrii. Filonowa koncepcja podwójnego stworzenia ma zatem swoje podstawy w nowej nauce o Bogu. Tak wyjaśnia to L. Joachimowicz: „Pod wpływem rygorystycznie pojmowanego dualizmu materii i ducha religia Izraela po niewoli babilońskiej mocno akcentowała transcendencję Boga w sposób uniemożliwiający jego bezpośrednią styczność z materią. W następstwie tego powstała potrzeba personifikowania przymiotów Boga mających spełniać rolę pośredniczącą pomiędzy Bogiem i światem"7.

Filon utożsamia owe Boskie przymioty $z$ platońskimi ideami, choć powiązal tę naukę także ze stoicką wizją Logosu. Według Filona Logos ,jest najwyższą ideą, jest ideą idei, a jak one są aniołami, tak on jest archaniołem, jest miejscem przebywania idei i ich miastem macierzystym, czyli jest treścią wszystkich idei, namiestnikiem Boga na ziemi, a jako poseł przekazuje i wykłada Boskie dekrety"8. Filon nie wyjaśnia, w jaki sposób powstały idee. Wydaje się, że odwiecznie istnieją w Logosie, który sam jest „niższy od Boga i należy go umie-

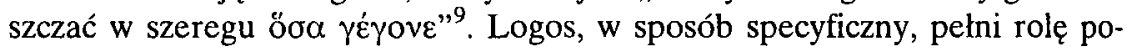

${ }^{5}$ Sw. Tomasz z Akwinu podaje następującą definicję stworzenia (STh 1, q. 65, a. 3): „Productio alicuius rei secundum suam totam substantiam, nullo praesupposito quod sit vel increatum vel ab aliquo creatum"; por. STh 1, q. 45, a. 4, ad 3; Franciscus Diekamp, Theologiae dogmaticae manuale, t. 2, Parisiis - Tornaci - Romae 1950, 2: „Recentiores idem sic exprimunt: Creatorem res producere ex nihilo sui et subiecti, id est neque eas ex sua substantia emanare facit neque ex materia praejacente producit".

${ }^{6} \mathrm{O}$ ile w przypadku Filona i Orygenesa można mówić z całą pewnością o wplywie Platona, o tyle u Grzegorza z Nyssy można się spierać, czy jego nauka jest inspirowana Platonem, czy raczej Plotynem i innymi przedstawicielami neoplatonizmu. Należy także pamiętać, że choć wszyscy trzej inspirowali się tradycją platońską, nie stronili także od innych systemów, wsród których na pierwszym miejscu należy wymienić stoicyzm.

${ }^{7}$ L. Joachimowicz, Wstęp. Filon - filozof alegoryzujq̨cy, w: Filon Aleksandryjski, Pisma, t. 1, Warszawa 1986, 22.

8 Tamże, s. 24.

${ }^{y}$ F. Copleston, Historia filozofii, t. 1, tłum. H. Bednarek, Warszawa 1998, 516; por. M. Osmański, Logos i stworzenie, s. 66. 
średnika między Bogiem a stworzeniem; M. Osmański tlumaczy tę rolę w ten sposób: „Bóg «myśli» idee dlatego, by «złożyć» z nich świat umysłowy, a ten staje się «wzorem» po to, by «stworzyć» świat materialny. Nie istnieją idec, które byłyby myślane niezależnie od wzoru lub które byłyby pozbawione mocy stwórczej, tak samo jak nie jest moźliwe stwarzanie bez doskonałego wzoru. Logos jest więc racją i zasadą jedności poszczególnych aspektów aktu stwórczego, umożliwia ich poznawcze ujęcie jako elementów koniecznych, nieoddzielalnych od stworzenia. Przede wszystkim jest jednak «myślą» Boga zwróconą w kierunku stworzenia" ${ }^{10}$. Nie tylko nie możemy jednoznacznie określić, jaki jest status ontyczny Logosu, ale nie da się również stwierdzić, czy Filon uważa Logos za byt osobowy, czy tylko bezosobowy pierwowzór wszystkich stworzeń ${ }^{11}$.

Tak czy owak, Logos, jako pośrednik między Bogiem i stworzeniem, zawiera w sobie idee wszystkich rzeczy:

„Jak zatem zaplanowane w umyśle architekta miasto nie miało miejsca na zewnątrz, ale było utrwalone $w$ jego duszy, tak samo świat stworzony $z$ idei nie miał gdzie indziej miejsca, lecz tylko w boskim Logosie, który to wszystko uporządkowal"12.

W odróżnieniu jednak od platońskich idei, Logos i idee są według Filona stworzone, choć jak pisze L. Joachimowicz „Logos ani nie jest niestworzony - jak Bóg, ani stworzony - jak ludzie, lecz pozostaje w środku między dwiema krańcowościami łącząc je ze sobą"13. Pierwsze stworzenie to zatem, wedkug Filona, utworzenie idei w Logosie (i samego Logosu):

„Bóg mianowicie w swojej boskiej mądrości wiedzial z góry, że piękne naśladownictwo nigdy nie może powstać bez pięknego modelu oraz że nie istnieje nic bez zarzutu wśród rzeczy postrzeganych zmysłami, co nie naśladuje prawzoru i umysłowej idei i dlatego zanim chciał stworzyć ten świat widzialny, stworzył najpierw świat umysłowy, aby następnie wykorzystując ten wzorzec niematerialny i podobny do Boga, stworzyć świat materialny, jako młode naśladownictwo starego wzoru"14.

W przypadku powstania świata, choć Bóg stwarza go za pośrednictwem innych bytów stworzonych, jednak On sam jest Stwórca. Gdy Filon dochodzi do opisu stworzenia człowicka, wprowadza pomocników, którzy mają być odpowiedzialni za zło, do jakiego skłonny jest człowiek:

${ }^{10}$ Osmański, Logos $i$ stworzenie, s. 65.

11 Por. Joachimowicz, Wstep. Filon - filozof alegoryzuigcy, s. 25.

12 Philo, De opificio mundi 20, thum. L. Joachimowicz: Filon Aleksandryjski, Pisma, t. 1, dz. cyt., s. 37. L. Joachimowicz wyjaśnia w przypisie 9: „Logos u Filona lączy wiele rodzajów przyczynowości, jak przyczynę sprawczą, instrumentalną i wzorczą, a prócz tego jest miejscem, gdzie się tworzą i znajdują idee".

13 Joachimowicz, Wstęp. Filon - filozof alegoryzujący, s. 25.

${ }^{14}$ De opificio mundi 16, thum. Joachimowicz, s. 36. 
„Dla Boga, Ojca wszechrzeczy, bylo najodpowiedniejsze stworzenie przez Niego jednego wszystkich stworzeń cnotliwych, ponieważ są mu pokrewne, ale też nie było dla Niego nieodpowiednie stworzenie istot obojętnych pod względem dobra i zła, ponieważ nie mają w sobie nic ze zła, którego on nienawidzi. Natomiast stworzenie istot mieszanej natury było dla niego odpowiednie i nieodpowiednie. Odpowiednie, ze względu na istniejącą w nich domieszkę lepszej idei, nieodpowiednie, ze względu na ideę przeciwną i gorszą. Dlatego tylko przy stworzeniu czlowieka jest wzmianka, że Bóg powiedział: «Uczyńmy», która wskazuje na to, że Bóg wziąl do pomocy innych wspóltwórców, tak aby nienaganne chęci i czyny slusznie postępującego czlowieka mogły być przypisane Bogu. Władcy wszechświata, a przeciwne - innym istotom, jemu podleglym. Bóg jako Ojciec nie mógl być dla swych dzieci sprawcą zła, a czymś złym jest występek i grzeszne uczynki”"15.

Powyższy opis dotyczy pierwszego stworzenia, czyli powstania człowieka idealnego, idei człowieka. Jak zwraca uwagę A.M. Mazzanti ${ }^{16}$, w tym fragmencie na pierwszy plan wysuwa się teodycea: Filon broni Boga przed zarzutem, iż mógłby być On w jakikolwiek sposób sprawcą zła. Przydając jednak Bogu pomocników, przyczynę zła umieszcza w ontologii.

Trudności pojawiają się, gdy próbujemy ustalić, która część człowieka jest stworzona przez Boga, a która przez pomocników i jakie wlaściwości miała powstała w pierwszym stworzeniu idea czlowieka. W dalszym ciągu dopiero co cytowanego opisu, Filon pisze:

„Bardzo też trafnie określił człowieka jako gatunek i rozróżnił jego rodzaje, kiedy powiedział, że stworzył go jako mężczyznę i niewiastę, chociaż poszczególne jednostki nie otrzymaty jeszcze wtedy postaci ludzkiej"17.

Zdaje się tu zatem przypisywać idei człowieka podział na płcie. W innym natomiast miejscu wyraźnie mówi, że płciowość jest cechą ludzi indywidualnych, nie noszących w sobie podobieństwa do Boga:

„Następnie powiedział: «Utworzył Bóg człowieka wziąwszy proch ziemi i tchnąl w oblicze jego dech życia». Wskazuje przez to wyraźnie, jak wielka zachodzi różnica pomiędzy tym człowiekiem, który teraz zostal stworzony a tamtym, który zostal stworzony wcześniej na podobieństwo Boga. Stworzony teraz człowiek był dostrzegalny zmysłami, miał określone wlaściwości, skladał się z duszy i ciała, był mężczyzną albo kobietą, a z natury śmiertelny. Tamten natomiast, stworzony na obraz Boga jest ideą, rodzajem albo pieczęcią. Jest istotą umysłową, niematerialną, nie jest mężzzyzną ani kobietą, jest nieśmiertelny z natury"18.

15 Tamzie 74-75, thum. Joachimowicz, s. 52-53; por. De fuga et inventione 68-72; De confusione linguarum 176-180; De mutatione nominum 30-31.

${ }^{16}$ Por. A.M. Mazzanti, Antropologia e radici del male in Filone di Alessandria: due possibili opzioni „Augustianum” 28 (1988) 190.

17 De opificio mundi 76, thum. Joachimowicz, s. 53.

18 Tamże 134, thum. Joachimowicz, s. 69. W Alegoriach praw (I 31) Filon rozróżniając ideę od pojedynczych ludzi mówi o czlowieku niebieskim i ziemskim. 
Słusznie jednak zauważa A.M. Mazzanti ${ }^{19}$, że, jakkolwiek by nie definiować idei czlowieka, istnieje między nią a jednostkowymi ludźmi radykalna różnica ontyczna. Trudno wyrokować, czy Filon mówi o różnicy chronologicznej, skoro utrzymuje, że wymiar czasowy powstał dopiero razem z rzeczywistością zmysłową:

„Powiedział: «Na początku stworzył Bóg niebo i ziemię» i rozumie przez to nie tak, jak sądzą niektórzy, początek w sensie czasu, ponieważ czas nie istniał przed światem, lecz raczej powstał równocześnie ze światem albo po nim"20.

G. Reale twierdzi, odwołując się także do Platonowego Timajosa, że stworzenie idei nie jest aktem dokonującym się w czasie, ponieważ wymiar czasowy powstał dopiero wraz ze światem zmysłowym. Uważa natomiast, że Filonowy człowiek idealny jest nie tylko logicznie i ontologicznie pierwszy w stosunku do człowieka złożonego z duszy i ciała, ale jest od niego także wcześniejszy chronologicznie, właśnie dlatego, że czas powstał dopiero ze światem ${ }^{21}$. Nie trzeba się jednak $z$ takim poglądem zgadzać, by zrozumieć ontyczną przepaść między światem idei a światem zmyslowym.

Gdzie jednak usadowione jest zło? Skoro wprowadzenie współtwórców do stworzenia człowieka miało w jakiś sposób „uchronić” Boga przed oskarżeniami o spowodowanie zła, to co konkretnie jest za nie odpowiedzialne? Wiadomo, że zostalo wprowadzone do człowicczego bytu przez owych wspóltworzycieli, czy jednak można utożsamić je z cielesnością? Poprawniej raczej bı̣luby powiedzieć, że w jakiś sposób z niej wynika. Byt cielesny jest bowiem z natury zmienny:

„Lecz wielki Mojżesz zrozumial, że to, co nie powstało, ma całkiem inną naturę niż rzeczy widzialne, ponieważ to, co jest postrzegalne zmysłami, podlega ciągłemu powstawaniu i zmianie, i nigdy nie trwa w tym samym stanie. Dlatego rzeczom niewidzialnym i poznawalnym przez umysł przypisywał wieczność jako pokrewną właściwość, natomiast rzeczy postrzegalne zmysłami określił nazwą im właściwą genezą"22.

Mimo tego zatem, że Filon pisał wcześniej o ontologicznej przyczynie zła, gdy dochodzi do konkretów woli mówić, że dzięki takiej a nie innej konstrukcji czlowiek jest nie tyle zmuszony, co „skłonny” do zła:

${ }^{19}$ Por. A.M. Mazzanti, L'aggettivo $\mu \varepsilon \theta$ óolos e la doppia creazione dell'uomo in Filone di Alessandria, w: La doppia creazione dell'uomo negli Alessandrini, nei Cappadoci e nella gnosi, Roma 1978, 29.

${ }^{20}$ De opificio mundi 26, thum. Joachimowicz, s. 38.

${ }^{21}$ Por. G. Reale, Historia filozofii starożytnej, t. 4, tłum. E.I. Zieliński, Lublin 1999, 308-309.

22 De opificio mundi 12, tłum. Joachimowicz, s. 35; podobnie tamże 151, thum. Joachimowicz, s. 74-75: „Ale ponieważ wśród rzeczy stworzonych nic nie jest trwałe, a wszystko, co śmiertelne, koniecznie musi podlegać zmianom i przeksztalceniom, zatem i pierwszy człowiek doznał skutków jakiegoś zlego uczynku". 
„Są wreszcic stworzenia mieszanej natury, jak czlowiek, który jest podatny na

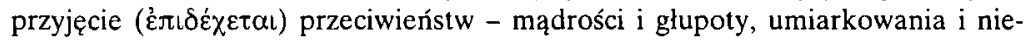
wstrzemięźliwości, odwagi i tchórzostwa, sprawiedliwości i niesprawiedliwości, i krótko mówiąc, jest skłonny do każdego dobra i zła, do szlachetnych i haniebnych uczynków, do cnoty i występku"23.

Lepiej zatem mówić o możliwości zla, niż o jego aktualnym istnieniu w człowieku, chociaż Filon rozróżnia jego zasadę ontologicznąą

Można zatem zadać sobie pytanie, czy podwójne stworzenie w jakikolwiek sposób pomogło Filonowi w wyjaśnieniu zagadki powstania zła i świata zmysłowego. Drugie stworzenie ma usprawiedliwić istnienie świata zmysłowego, do którego filozofowie greccy odnosili się co najmniej z nieufnością ${ }^{25}$. Filon daleki jest jednak od całkowitego odseparowywania Boga i świata. Bóg jest bowiem stwórcą nie tylko świata inteligibilnego, ale i wszystkich bytów szczegółowych i wszystkie te byty podtrzymuje w istnieniu. Logos i idee są jedynie modelami lub przyczynami wzorczymi, Bóg stworzył je po to, by dzięki nim mógl powstać doskonale uporządkowany świat fizyczny ${ }^{26}$. Nie można też powiedzieć, by Filon uznawał drugie stworzenie czy cielesność za przyczynę zła. A zatem, choć może chciał dzięki koncepcji podwójnego stworzenia wyjaśnić znaną nam postać świata, nie tyle ją wyjaśnił, co raczej opisał jej początki, łącząc po raz pierwszy prawdę objawioną z filozoficznym opisem struktury świata.

2. Orygenes. Chociaż zabrzmi to jak banał, muszę na początku zwrócić uwagę, że nauka Orygenesa jest dla nas najtrudniejsza do odtworzenia. Oprócz trudności samych tekstów, niejasności a niekiedy wykluczania się pewnych wypowiedzi, z czym spotkaliśmy się już przy okazji omawiania Filona, tu pojawia się czynnik dodatkowy: zaginięcie lub zniekształcenie podstawowych dla tematu podwójnego stworzenia dzieł Orygenesa. Przede wszystkim zaginąl Komentarz do Księgi Rodzaju, a po wtóre traktat $O$ zasadach znamy jedynie w - nazwijmy tekst Rufina optymistycznie - tłumaczeniu.

Długo uczeni skłonni byli przyznawać, że Orygenes uważa pierwszy opis stworzenia człowieka z Księgi Rodzaju za opis pierwszego stworzenia, w wyniku którego powstał świat umysłów, czlowiek na obraz, preegzystujący, natomiast drugi opis miał odpowiadać stworzeniu świata zmyslowego, w tym człowieka obdarzonego ziemskim ciałem, które to stworzenie nastąpilo na

23 Tamże 73, tłum. Joachimowicz, s. 52.

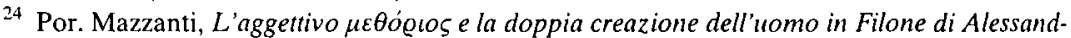
ria, s. 37.

25 Nieufnosć ta dotyczyła głównie zmysłowości człowieka. Zwłaszcza tradycji platońskiej często zdarzało się używać orfickiego określenia ciała jako więzienia duszy lub mówić o ciele jako o narzędziu duszy, por. Reale, Historia filozofii starożytnej, t. 5, thum. E.I. Zieliński, Lublin 2002, 47.

26 Por. Reale, Historia filozofii starożytnej, t. 4, dz. cyt., s. 309. 
skutek upadku bytów umysłowych ${ }^{27}$. Jednak już w 1962 r. M. Simonetti ${ }^{28}$ ogłosił swoje odkrycie wielce znaczącego tekstu Prokopiusza z Gazy ${ }^{29}$, będącego komentarzem do zaginionego dzieła Orygenesa o Księdze Rodzaju. Interpretacji opartej na tym tekście broni od 1979 r. także H. Crouzel ${ }^{30}$. Tekst ten rozwiązuje problem, powiedzmy, chronologiczny: skoro Orygenes wiąże powstanie zmysłowego człowieka $\mathrm{z}$ jego wcześniejszym upadkiem, to jak wytłumaczyć, że opis powstania tegoż człowieka znajduje się $\mathrm{w}$ rozdziale drugim, a opis upadku w następnym? Prokopiusz zaświadcza, że Orygenes rozwiązał ten problem następująco: drugi rozdział opisuje stworzenie ciała eterycznego „połyskującego" i należy je uznać za jednoczesne z powstaniem samych umysłów. Dopiero zatem trzeci rozdział przynosi nam opis drugiego stworzenia, w czasie którego w wyniku upadku powstał świat zmysłowy.

Nie jest natomiast jasne, jak Orygenes mógł interpretować Rdz 2, 21-25, gdzie znajduje się opis stworzenia mężczyzny i kobiety. H. Crouzel ${ }^{31}$ zdaje się sugerować, że mógł w tym opisie widzieć związek Chrystusa i Kościoła, ale tego możemy się jedynie domyślać.

Niezależnie od tego, którą interpretację uznamy za bardziej przekonywającą, kilka punktów zasługuje na wyszczególnienie. Najważniejsze pytanie dotyczy właściwości intelektów powstałych w pierwszym stworzeniu. Należy przede wszystkim zapytać o ich cielesność, zwłaszcza że odpowiedź ma znaczące konsekwencje. Orygenes uznaje bowiem, że zmartwychwstanie będzie powrotem do stanu pierwotnego ${ }^{32}$, jeśli więc przyznaje intelektom status bytów duchowych, negowałoby to możliwość zmartwychwstania ciał ${ }^{33}$. W przekazie Prokopiusza z Gazy Orygenes wyraźnie przypisuje intelektom ciała eteryczne, jednak nawet zachowane teksty dają podstawy do uznania, że intelekty były rzeczywiście w jakimś sensie obdarzone cielesnością.

We wprowadzeniu do traktatu $O$ zasadach Orygenes wyjaśnia, że niecielesność można rozumieć na dwa sposoby. Następująco komentuje cytowane

${ }^{27}$ Por. H. Crouzel, L'image de Dieu dans la théologie d'Origène „Studia Patristica” 2 (1957) 197; G. Sfameni Gasparro, Doppia creazione e peccato di Adamo nel Peri Archon di Origene: Fondamenti biblici e presupposti platonici dell'esegesi origeniana, w: La doppia creazione dell'uomo negli Alessandrini, nei Cappadoci e nella gnosi, dz. cyt., s. 49.

${ }^{28}$ Por. M. Simonetti, Alcune osservazioni sull'interpretazione origeniana di Genesi 2,7 e 3, 21 „Aevum" 36 (1962) 370-381.

${ }^{29}$ Tekst ten znajduje się w Commentarii in Genesin 21, PG 87/1, 221.

${ }^{30}$ Por. H. Crouzel, L'anthropologie d'Origène: de l'arche à telos, w: Arché e Telos. $L$ 'antropologia di Origene $e$ di Gregorio di Nissa. Analisi storico-religiosa. Atti di colloquio (Milano 17-19 maggio 1979), Milano 1981, 43; zob. ponadto H. Crouzel, Orygenes, thum. J. Margański, Bydgoszcz 1996, 136 i 291.

${ }^{31}$ Por. Crouzel, Orygenes, s. 291.

32 Por. De principiis II 1, 1, SCh 252, 236, tłum. S. Kalinkowski: O zasadach, ŹMT 1, Kraków 1996, 139: „Koniec świata przywróci wszystko do pierwotnego stanu”.

${ }^{33}$ Por. Sfameni Gasparro, Doppia creazione e peccato di Adamo nel Peri Archon di Origene, s. 51. 
przez przeciwników zdanie $\mathrm{z}$ apokryficznej Nauki Piotra, stwierdzające, że Zbawiciel nie jest dajmonionem niecielesnym:

„Słowa owe należy rozumieć zgodnie z myślą autora tej książeczki, to znaczy, że Zbawiciel nie ma takiego ciała jak demony - ciało demonów jest $\mathrm{z}$ natury delikatne i przejrzyste i dlatego większość ludzi uważa je za niecielesne i tak je nazywa - lecz ma ciało masywne i dotykalne. A wszystko, co nie jest takie, ludzie prości i naiwni zgodnie ze swym zwyczajem nazywaja niecielesnym; to tak, jakby ktoś nazwal niecielesnym powietrze, którym oddychamy, bo nie jest ono ciałem, które można uchwycić i trzymać i które stawia opór, gdy je nacisnąç ${ }^{34}$.

W innym miejscu uzupełnia to wyjaśnienie o stwierdzenie, że tylko Bogu przysługuje niecielesność $w$ sensie ścisłym, wszystkie stworzenia zaś, nawet aniołowie i demony są cielesne, choć ich ciała są „delikatne" i ,przejrzyste”:

„Gdy się bada, czy istnieje jakaś substancja, przy której nie można pomyśleć o kolorze, wyglądzie, dotyku ani wielkości, a która jest dostrzegalna wylącznie dla umysłu, każdy nazywa ją jak chce: Grecy nazywają ją substancją asomatyczną, to znaczy niecielesną, natomiast Pismo święte nazywa ją substancją niewidzialną. Apostol głosi bowiem, że Bóg jest niewidzialny, powiada, że «Chrystus jest obrazem niewidzialnego Boga». Mówi też, że przez Chrystusa zostało stworzone wszystko, «rzeczy widzialne i niewidzialne». Stwierdza w ten sposób, że także wśród stworzeń istnieją jakieś istoty niewidzialne w swej istocie. One jednak, chociaż same nie są cielesne $\mathbf{i}$ chociaż są doskonalsze od substancji cielesnej, posluguja się przecież ciałami. Co się zaś tyczy istoty owej Trójcy, która jest początkiem i przyczyną wszystkich rzeczy, «z której, przez którą i w której jest wszystko», to należy wierzyć, że nie jest Ona ciałem ani nie istnieje w ciele, lecz jest całkowicie nieciclesna" ${ }^{\text {35. }}$

Nic oznacza to bynajmniej, że dusza jest cielesna. Tak wyjaśnia ten problem H. Crouzel: „,Dusza jest bezsprzecznie niecielesna, niemniej zawsze zespolona $\mathrm{z}$ ciałem. Ciało, znak statusu stworzenia, wyraża jego akcydentalność w przeciwstawieniu do substancjalności Trzech Osób, co oznacza, iż stworzenic otrzymało wszystko, co posiada i ze wszystko to posiada w sposób nietrwały, zależny od impulsów wolnej woli"36. A zatem czlowiek powstały w pierwszym stworzeniu byl cielesny, choć jego ciało było z gatunku subtelnych i niewidzialnych. Jeśli przyjmiemy, że opis obu stworzeń zamyka się w dwóch pierwszych rozdziałach Księgi Rodzaju, musimy przyznać, ze świat powstały w pierwszym

${ }^{34}$ De principiis I Praefatio, 8, SCh 252, 86, ŹMT 1, 56. H. Crouzel dopowiada, że istnieje także trzecie znaczenie słowa niecielesność (Orygenes, dz. cyt., s. 135): „Może oznaczać sposób życia, oddalenie niedozwolonych pożądań ciała, a zatem mieć znaczenie związane z porządkiem moralnym: odnosi się do istot zażywających wiecznej szczęśliwości jak również, dość często, aczkolwiek w sposób rzecz jasna względny, do sprawiedliwych żyjących nadal na ziemi".

${ }^{35}$ De principiis IV 3, 15, SCh 268, 396, ŹMT 1, 367; por. tamże I 6, 4 oraz II 2, 2.

36 Orygenes, dz. cyt., s. 135. 
stworzeniu już był cielesny. Jeśli natomiast przyjmiemy wersję Prokopiusza, ukaże się naszym oczom stworzenie intelektów i okrywających je świetlistych ciał, opisane w dwóch pierwszych rozdziałach oraz przybranie przez owo ciało odzienia ze skór, symbolizującego ciężką i doczesną jakość. W każdym razie jedno nie ulega kwestii: wszystkie stworzenia są cielesne, a ponadto Orygenes „zamierzał podtrzymać tezę zarówno o tożsamości substancji, jak i o różnicy jakości między ciałem ziemskim a ciałem zbawionym, które upodabnia się do eterycznych ciał anielskich"37.

Drugie ważne dla nauki o podwójnym stworzeniu zagadnienie to przyczyna drugiego stworzenia. Orygenes pisząc o duszy wyodrębnia jej dwie części:

„Jedną jej cząstkę nazwiemy lepszą - tę, która została stworzona «na obraz i podobieństwo Boże», druga zaś część, ta, która została przybrana późnicj wskutek upadku wolnej woli wbrew naturze pierwszego stworzenia i czystości, jako droga przyjaciólka cielesnej materii będzie podlegać karom «wraz z niewiernymi»"38.

Jakakolwiek była przyczyna samego upadku: czy był nią przesyt w oglądaniu Boga $^{39}$, czy raczej oziębienie gorliwości ${ }^{40}$, to właśnie ów upadek jest przyczyną zróżnicowania stworzeń rozumnych:

„Wydaje mi się, że degradacja i upadek rozumu nie jest bynajmniej jednakowy u wszystkich istot, przeciwnie - rozum przemienia się w duszę w większym lub mniejszym stopniu: niektóre umysły zachowuja pewną cząstkę dawnego żaru, a inne nie mają go wcale lub prawie wcale. Dlatego też niektórzy ludzie od samych narodzin dysponują bystrym umysłem, inni mają mniejsze zdolności, a jeszcze inni są tępi i zupelnie niezdolni” ${ }^{41}$.

Nauka Orygenesa o preegzystencji dusz, upadku i podwójnym stworzeniu ma na celu przeciwstawienie się determinizmowi zarówno astrologii, jak i wszelkiej maści gnostycyzmowi ${ }^{42}$. Całą odpowiedzialność nie tylko za zło, ale za wszelkie nierówności obecnego życia składa bowiem na karb wolnej woli stworzeń rozumnych.

To prawda, że Bóg jest sprawcą także drugiego stworzenia, ale uczynil je tylko dlatego, że stworzył istoty rozumne wolnymi, a więc zdolnymi także do odejścia od Niego i taki ich wybór uszanowal. Aby dać wyobrażenie o wadze i skutkach upadku w preegzystencji, Orygenes porównuje nawet drugie stworzenie do sądu analogicznego do Sądu ostatecznego:

37 Tamze, s. 137.

${ }^{38}$ De principiis II 10, 7, SCh 252, 390-392, ŹMT 1, 212.

${ }^{34}$ Por. tamze I 3,8 oraz I 4,1 .

40) Por. tamże II 8, 3-4.

41 Tamze II 8, 4, SCh 252, 348, ŹMT 1, 192.

42 Por. Crouzel, Orygenes, dz. cyt., s. 282 oraz Sfameni Gasparro, Doppia creazione e peccato di Adamo nel Peri Archon di Origene, s. 58. 
„Można zatem przypuszczać, że i dawniej istniały naczynia rozumne bardziej lub mniej oczyszczone, czyli takie, które same się oczyściły lub nie oczyściły i dlatego właśnie każde naczynie stosownie do swej czystości albo skalania otrzymalo miejsce, krainę albo stan narodzenia i obowiązek dopełnienia określonych czynów; o wszystkie te naczynia, aż do najmniejszego, Bóg troszczy się mocą swej mądrości i rozpoznaje je w miarę swego sądu; wszystkie je rozmieścił za pomocą najsprawiedliwszej odpłaty, gdyż każdemu należała się wedle zasług pomoc lub porada. I w tym objawia się najpełniej cała istota sprawiedliwości, skoro nierówność rzeczy zachowuje równość zaslużonej odpłaty. Istotę owych zasług we wszystkich poszczególnych bytach zna prawdziwie i dokładnie tylko sam Bóg wraz z jednorodzonym Słowem i Mądrością oraz ze swym Duchem Świętym"43.

Koncepcja Orygenesa thumaczy zatem konsekwentnie nie tylko powstanie świata zmysłowego, ale także przyczynę zła i zróżnicowania stworzeń rozumnych, podkreślając, że ich wolna wola stała się przyczyną znanej nam rzeczywistości.

3. Grzegorz z Nyssy. Zanim spróbuję przybliżyć specyfikę koncepcji stworzenia Grzegorza, muszę ustalić, czy rzeczywiście mówi on o podwójnym stworzeniu. Jego stwierdzenia na ten temat wydają się być aż nadto jednoznaczne, a jednak pojawiły się głosy podważające takie rozumienie jego myśli ${ }^{44}$. Prawdą jest, że Grzegorz nie opiera się, tak jak Filon i Orygenes, na dwóch opisach stworzenia zawartych w Biblii, a jednak wyraźnie mówi, że „stworzenie naszej

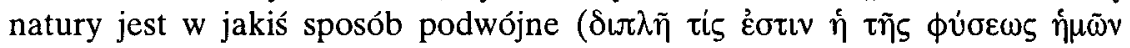

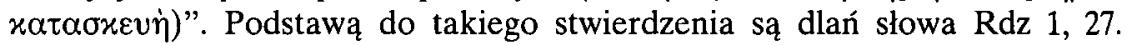
Grzegorz uznaje pierwszą część wersu: „Stworzył więc Bóg człowieka na swój obraz, na obraz Boży go stworzyl", za opis pierwszego stworzenia, w wyniku którego powstała ludzka natura i było to stworzenie „na Boże podobieństwo", natomiast zdanie: „stworzył mężczyznę i kobietę” odnosi do drugiego stworzenia „charakteryzującego się owym rozróżnieniem" "45 przy czym „rozróżnienie

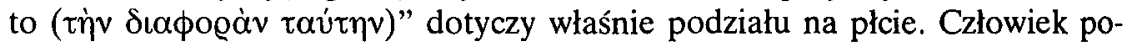
wstały w wyniku pierwszego stworzenia, nie był to nasz praojciec Adam, bo nie byl to człowiek indywidualny, ale cala ludzka natura:

„Pismo mówiąc, że Bóg stworzył człowieka, za pomocą nieokreślonego terminu ukazuje całą ludzkość. To stworzenie nie zostało jeszcze nazwane Adamem, jak to mówi dalsze opowiadanie. Imię nadane stworzeniu nie było indywidualne, ale ogólne. Przez powszechną nazwę natury każe nam rozumieć, że dzięki Bożemu przewidywaniu i mocy w pierwszym stworzeniu została zawarta cała ludzkość ${ }^{46}$.

${ }^{43}$ De principiis II 9, 8, SCh 252, 370, ŹMT 1, 204; por. tamże II 1, 1.

${ }^{44}$ Por. E. Corsini, Plérôme humain et plérôme cosmique chez Grégoire de Nysse, w: Ecriture et culture philosophique dans la pensée de Grégoire de Nysse. Actes du colloque de Chevetogue. Leiden 1971, 111-126.

45 De opificio hominis 16, PG 44, 181.

46 Tamze 16, PG 44, 185. 
To, co powstało w wyniku drugiego stworzenia, jest naznaczone podziałem na płcie, którego w Bogu nie ma. Grzegorz utrzymuje, że Bóg dokonał drugiego stworzenia przewidując grzech człowieka:

„Ten, który zna wszystko zanim powstało, jak mówi proroctwo, poznawszy, lub raczej przewidziawszy dzięki swojej mocy przewidywania, w jakim kierunku zwróci się dzięki władzy nad sobą ludzka zdolność wyboru, skoro zobaczył to, co dopiero miało nastąpić, wprowadził do obrazu różnicę między męskością a kobiecością, która nie spogląda już na Boski wzór, ale jak powiedziałem, wiąże się $\mathrm{z}$ naturą nierozumną, ${ }^{47}$.

Grzegorz widzi zatem głęboką różnicę między stworzeniem uczynionym na Boży obraz, a tym, w którym obecny jest podział na kobietę i mężczyznç. Nie ma więc wątpliwości, że te dwic rzeczywistości są w jakiś sposób rozdzielone: „czym innym jest to, co powstało na obraz Boży, a czym innym to, co teraz ukazuje się [obarczone] cierpieniem" ${ }^{\text {48 }}$. Widzimy, że podział na płcie nie jest dla Grzegorza jedynym argumentem na to, że jedynie pierwsze stworzenie człowicka było stworzeniem na obraz Boży, jest nim także cierpienie oraz inne cechy, charakteryzujące obecny stan ludzi, jak namiętności, ból, śmierć. A jednak trzeba wyraźnie oddziclić podział na płcie od innych wymienionych przed chwilą cech. Problemowi temu przyjrzę się za chwilę. Najpierw zajmę się kilkoma podstawowymi zagadnieniami, wiążących się z Grzegorzową koncepcją podwójnego stworzenia.

Nie da się stwierdzić z całą pewnością, czy pierwsze stworzenie jest oddzielone od drugiego czasowo, choć może na to wskazywać fragment, w którym Grzegorz wyjaśnia moment powstania duszy ludzkiej u nowo poczętego dziecka. Mówi on mianowicie, ze dusza powstaje razem z ciałem „w odróżnieniu” od powstania ludzkiej natury i jednostkowych ludzi:

„Jako że człowiek złożony z duszy i ciała stanowi jedność, należy założyć, że jeden i ten sam jest fundament i duszy, i ciała, bo gdyby element cielesny pojawił się wcześniej, a duchowy później, czlowiek byłby starszy lub młodszy od siebie samego. Lecz, jak to już powyżej stwierdziliśmy, najpierw, dzięki przewidującej Bożej mocy, zaistniała cała pelnia ludzkości, a i proroctwo to zaświadcza mówiąc, że Bóg poznał wszystko zanim zaistniało. Natomiast w powstawaniu poszczególnych bytów jedno nie poprzedza drugiego: ani dusza ciała, ani odwrotnie"49.

Grzegorz wyraźnie przeciwstawia tu jednoczesne powstanie duszy i ciała uprzedniemu powstaniu ludzkiej natury. Jeśli nawet nie uznamy tego argumentu, przyznać trzeba, że stworzenie na obraz Boży jest pierwsze ontycznie i logicznie.

\footnotetext{
47 Tamzie.

48 Tamże 16, PG 44, 181.

49 Tamże 29, PG 44, 233.
} 
Przyjrzyjmy się teraž, jak Grzegorz określa to, co powstało w wyniku pierwszego stworzenia. Podstawowy wyklad nauki Grzegorza o podwójnym stworzeniu znajdujemy w jego traktacie De opificio hominis, przede wszystkim w rozdziałach 16 i 22 . Wyróżniając dwa akty (czy może lepiej: etapy lub wymiary) stworzenia człowieka, próbuje on odpowiedzieć na pytanie, jak to jest możliwe, że czlowiek, stworzony na Boży obraz, może być mężczyzną lub kobietą, mimo że w Bogu nie ma podziału na płcie. Grzegorz wyjaśnia, że obecny stan ludzkości nie ma w sobie cech Bożego obrazu. Obrazem Boga jest to, co powstało w wyniku pierwszego stworzenia, a więc cała ludzka natura, rozumiana jako swoista jedność: „Cała natura rozciągająca się od pierwszych do ostatnich jest jednym obrazem Tego, który jest"50.

Czym jednak jest jedność ludzkiej natury? Grzegorz porównuje ją do jedności natury anielskiej, której z kolei nie waha się nazwać jedną substancją: „Stanowią jedną substancję, a jednak można naliczyć ich wielu"51. Traktat De opificio hominis nie wyjaśnia nam tak naprawdę, na czym owa jedność polega. Więcej na ten temat napisze Grzegorz nieco później, między innymi w drobnych pismach trynitarnych, gdzie podaje następującą definicję natury:

„Natura jest jedna i zjednoczona sama ze sobą, jest całkowicie niepodzielną monadą, nierosnącą przez dodanie ani niemalejąca przez ubytek, lecz jest jednością i pozostaje jednością, chociaż ukazuje się w wielości, niepodzielna, trwała, nienaruszalna i nie dzieli się pomiędzy uczestniczących w niej"52.

Grzegorz rozumie naturę jako jedną oủoía. Dlatego w dziełku O rozróżnieniu między istotq a hipostazq nazywa ludzi ó oov́oı $^{53}$. Również gdzie indziej rozwija tę myśl: „O Piotrze, Pawle i Barnabie nie mówimy, że są trzema substancjami, bo substancja tych osób jest jedna"54. Wyprowadza stąd wniosek, że niesłusznie mówi się o wielu ludziach, skoro istnieje tak naprawdę tylko jeden człowiek:

„To, co jest tym samym, nie może być w tym samym sensie jednocześnie jedno i wiele. Według powszechnego uznania Piotr, Paweł i Barnaba pod względem pojęcia czlowieka są jednym człowiekiem, więc w tym samym sensie tzn. w sensie pojęcia człowieka, nie są wieloma. Sa jednak nazwani wieloma ludźmi, oczywiście w niewłaściwy sposób i nie we właściwym sensie" ${ }^{\text {" } 5}$.

50 Tamże 16, PG 44, 185.

51 Tamże 17, PG 44, 189.

52 Ad Ablabium, quod non sint tres dei, GNO 3/1, 41; tłum. T. Grodecki: Św. Grzegorz z Nyssy, Do Ablabiusza o tym, że nie można mówić, że jest trzech Bogów, ŹMT 21, Kraków 2001, 106.

53 Por. De differentia essentiae et hypostaseos (Ps. Basilii, Ep. 38), PG 32, 325-340, thum. W. Krzyżaniak: O rozróżnienilı między istolą a hipostazq, ŹMT 21, 70.

54 Ad Graecos ex communibus notionibus 6, GNO 3/1,23, thum. T. Grodecki, ŹMT 21, 94; por. Contra Eunomium I 1, 495; Refutatio confessionis Eunomii 59, 4.

${ }^{55}$ Ad Graecos ex communibus notionibus 11, GNO 3/1, 25, thum. T. Grodecki, ŹMT 21, 97; por. Contra Eunomium III 4, 55. 
A zatem indywidualni ludzie są jedynie przejawami jednej substancji, nie są w rzeczywistości wieloma.

Wiele miejsca w De opificio hominis poświęca Grzegorz określeniu, czym jest $\pi \lambda \eta \dot{ } \varrho \omega \alpha$ ludzkiej natury. To pojęcie jest podstawowe dla zrozumienia relacji pomiędzy ludzką naturą a poszczególnym, jednostkowym człowiekiem, dlatego warto, jak sądzę, przytoczyć cały długi fragment dotyczący tego problemu:

„Pismo mówiąc, że Bóg stworzył człowieka, za pomocą nieokreślonego terminu ukazuje calą ludzkość. To stworzenie nie zostało jeszcze nazwane Adamem, jak to mówi dalsze opowiadanie ${ }^{56}$. Imię nadane stworzeniu nie było indywidualne, ale ogólne. Przez powszechną nazwę natury każe nam rozumieć, że dzięki Bożemu przewidywaniu i mocy w pierwszym stworzeniu została zawarta cała ludzkość. Trzeba uznać, że nie ma dla Boga nic nieokreślonego wśród tego, co stworzył, ale każde ze stworzeń ma swoją granicę i miarę, określoną przez mądrość Stwórcy. Jak poszczególny czlowiek jest określony ciężarem ciała i miarą dla niego są wymiary substancji, które rozciągają się tak samo jak powierzchnia ciała, podobnie sądzę, że jakby w jednym ciele Bóg, dzięki swej przewidującej mocy, zawarł całą pełnię ludzkości i o tym właśnie mówi Pismo w słowach: Stworzył Bóg czlowieka, na obraz Boży go stworzył. Obraz [Boży] nie istnieje bowiem w jakiejś części natury ani łaska w jakimś z jej zewnętrznych przejawów, ale ta moc rozciąga się na caly rodzaj ludzki [...] Cała więc natura rozciągająca się od pierwszych do ostatnich jest jednym obrazem Tego, który jest" ${ }^{\text {"57. }}$.

Można powiedzieć, że $\pi \lambda \eta \dot{\eta} \varrho \mu \alpha$ określa rozciagłość ludzkiej natury: liczbę ludzkich jednostek, które się w niej zawierają. Jest to pełnia jeszcze nie zrealizowana, ale chyba nie byłoby poprawnym stwierdzenie, ze jest ona tylko potencjalna, jeśli rozumie się potencjalność jako możliwość zaistnienia. Jest ona ściśle określona i zrealizuje się z całą pewnością w historii świata od dnia stworzenia do dnia ostatniego:

„Powstał zatem na obraz czlowiek, [czyli] cała natura, dzieło podobne do Boga. Dzięki wszechmocnej mądrości powstała nie część całości, ale cała połączona pełnia natury. Ten, który obejmuje wszystkie krańce ziemi - jak mówi Pismo: «W Jego ręku są krańce ziemi» - Ten, który zna wszystko zanim powstanie, ogarnąwszy myślą wiedzial [już] jak wielka pod względem liczby [osób] będzie ludzkość"ss.

Dopiero wtedy ,gdy pełnia ludzkiej natury dojdzie do swoich granic zgodnie z wyznaczoną jej miarą" ${ }^{59}$, nastąpi koniec czasów i zmartwychwstanic umarlych.

${ }^{56}$ Podobnie Orygenes (Contra Celsum IV 40, tłum. S. Kalinkowski, Warszawa 1986, 210-211): „To, co Mojżesz mówi o Adamie, odnosi się do natury ludzkiej. Albowiem powiada Pismo: «w Adamie wszyscy umierają" i zostali potępieni za "przestępstwo podobne do przestępstwa Adama». Tak więc Pismo Swięte mówi nie o jednym człowieku, lecz o całym rodzaju ludzkim".

57 De opificio hominis 16, PG 44, 185.

58 Tamże 22, PG 44, 204.

59 Tamże 22, PG 44, 205. 
Co jednak oznacza dojście pełni ludzkiej natury do kresu? Oznacza to narodzenie się określonej liczby osób. Grzegorz stanowczo odrzuca przypuszczenie, że gdyby nie grzech i wprowadzenie podziału na płcie, które jest jego skutkiem, natura ludzka nie mogłaby tej pełni zrealizować. Uważa bowiem, że także natura anielska, która jest jednością podobnie, jak ludzka i która również ma określoną pełnię, realizowaną w czasie, w jakiś tajemniczy sposób wydaje $\mathrm{z}$ siebie mnóstwo jednostek:

„Jeśli ktoś bardzo chce znać sposób, w jaki rozmnażalby się czlowiek, gdyby nie potrzebował do tego małżeństwa, zapytamy go i my o to samo odnośnie aniolów: w jaki sposób jest ich nieprzeliczone mnóstwo; są oni bowiem jedną substancją, a jednak można naliczyć ich wielu"60).

Gdyby nie grzech, nie byłoby zatem drugiego stworzenia, czyli nie byłoby podziału na mężczyznę i kobietę, a jednak ludzka natura, nie przestając być jedną substancją (oủoía), zrealizowałaby się w wielu indywidualnych jednostkach. Tak zatem podsumowuje Grzegorz stworzenie czlowieka:

„Ten, który wszystko powoluje do istnienia, ukształtowawszy najpierw w swojej woli calego człowieka na Boży obraz, nie czekal na powolne uzupelnianie [ludzkości] przez rodzących się, lecz poznał wypełnioną liczbę dusz według własnej pełni. Poznawszy lącznie w jej pełni całą ludzką naturę dzięki swojej władzy przewidywania, ozdobiwszy ją udziałem w godności wyższej i równej aniołom, gdy przewidzial, że wolny wybór nie zwróci się ku dobru, lecz odejdzie od anielskiego życia, wtedy, aby nie uszczuplać pelni dusz ludzkości, skoro porzuciła ów sposób, w jaki aniołowie wzrastali w liczbę aż do pełni, przeznaczył naturze sposób wzrastania odpowiedni dla tych, którzy ześlizgnęli się w grzech" ${ }^{\text {"61. }}$.

We fragmencie tym występują wszystkie trzy najistotniejsze dla zrozumienia naszego zagadnienia pojęcia, których nie można ze sobą utożsamiać. Pierwszym jest pojęcie ludzkiej natury, drugie to konkretny czlowiek, uczestniczący w ludzkiej naturze, ale obarczony płciowością; trzecie to pełnia $(\pi \lambda \eta \dot{\eta} \omega \mu \alpha)$ ludzkiej natury.

Trzeba przyznać, że Grzegorz niewiele miejsca w De opificio hominis poświęca samej „ludzkiej naturze”, dlatego, by coś o niej powiedzieć, trzeba odwoływać siç do innych jego pism. Nie oznacza to jcdnak, że należy stawiać znak równości między „naturą ludzką” a jej $\pi \lambda \eta \dot{\eta} \varrho \omega \alpha$. Mam wrażenie, że ci badacze, którzy na podstawie De opificio hominis odmawiali realności „ludzkiej naturze", mieli tak naprawdę na myśli właśnie jej $\pi \lambda \eta \eta_{\emptyset} \omega \mu \alpha$. Nic ma bowiem wątpliwości, że $\pi \lambda \eta \dot{\varrho} \omega \mu \alpha$ należy do, jak ujął to J. Daniélou ,porządku zamierzonego" (l'ordre intentionnel) ${ }^{62}$, nic oznacza to jednak, że „ludzka

60 Tamże 17, PG 44, 189.

61 Tamże 17, PG 44, 189.

62 J. Daniélou (Platonisme et Théologie mystique. Essai sur la doctrine spirituelle de saint Grégoire de Nysse, Paris 1944, 57) uważa, że ludzka natura istnieje tylko w Bożym zamyśle. 
natura" do takiego porządku należy i nie ma swojej, odrębnej od ludzkich osób, realności. Wydaje się, że Grzegorzowe wyobrażenie ludzkiej natury pozostaje pod wpływem platońskiej koncepcji idei lub neoplatońskiego umysłu czy duszy. Można bowiem rozumieć udzial jednostek w ludzkiej naturze na zasadzie platońskiego uczestnictwa rzeczy w idei lub na zasadzie zależności bytu niższego od wyższego, jak u Plotyna. Grzegorzowa ludzka natura przypomina idę, umyst lub duszę, ponieważ, tak jak one, stanowi niepodzielną jedność, która zawiera w sobie wielość, jest w każdej z tworzących się z niej części, a jednak pozostaje transcendentnym bytem.

Kwestią o znaczeniu nie do przecenienia jest pytanie o cielesność ludzkiej natury. Chociaż Grzegorz uznaje płciowość za skutek przewidzianego grzechu, nigdy nie wypowiada podobnego zdania na temat cielesności człowieka. Wydaje się zatem, że przypisujc on „ludzkiej naturze" powstałej w wyniku pierwszego stworzenia aspekt cielesny. Wlaściwie nigdzie nie mówi o tym wprost. Mamy jednak przesłanki, by tak sądzić. Kiedy Grzegorz mówi o Wcieleniu używa sformułowania: „Całe ciało naszej natury zostało zmieszane z Boską i niezmienną naturą"63. Można uznać ten fragment jedynie za poetyckie porównanie. Nie da się jednak w ten sam sposób zinterpretować opisu ciał po zmartwychwstaniu: „Zobaczysz bowiem - pisze Grzegorz - jak ta cielesna osłona, choć śmierć ją rozerwie, $\mathrm{z}$ tego samego materiału znów będzie kiedyś

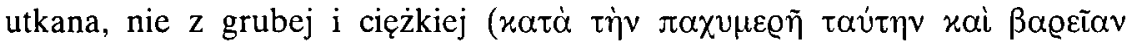

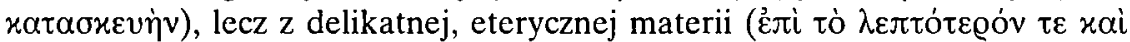

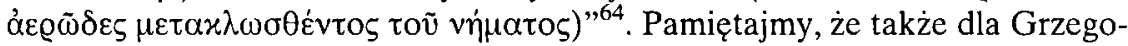
rza, tak jak dla Orygenesa, zmartwychwstanie oznacza powrót do początku ,jest przywróceniem naszej natury do stanu, jaki miała na początku ${ }^{65}[\ldots]$, wiedzie do pierwotnej laski" ${ }^{\text {"66 }}$, czyli tak naprawdę do stanu pierwszego stworzenia. Oznaczałoby to, że „ludzka natura” jest cielesna, choć nie jest to ciało „Zwierzęce" ${ }^{, 67}$, czyli takie, jakie mają indywidualni ludzie po grzechu.

Także przy opisie natury anielskiej, Grzegorz mówi, że jest ona w jakiś sposób cielesna:

„Aniołowie zaś, należąc do kategorii bytów niewidzialnych, przebywają ponad światem i niebem, ponieważ ta siedziba jest odpowiednia dla ich bezcielesnej natury (albowiem natura rozumna jest delikatna, czysta, lekka i zwinna, jak i ciało

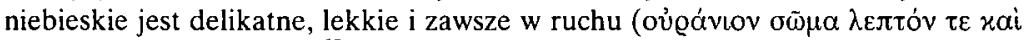

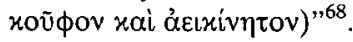

${ }^{63}$ In illud: Tunc et ipse Filius, PG 44, 1316.

${ }^{64}$ Dialogus de anima et resurrectione, PG 46, 108A, thum. W. Kania: Sw. Grzegorz z Nyssy, Wybór pism, PSP 14, Warszawa 1974, 65.

65 Tamże, PG 46, 148B; PSP 14, 81.

66 Tamże, PG 46, 157; PSP 14, 86.

${ }^{67}$ Por. Oratio catechetica magna 8, tłum. W. Kania, PSP 14, 142-143.

${ }^{68}$ De infantibus praemature abreptis 23 , GNO 3/2, 78, thum. M. Przyszychowska, BOK 23, 72. 
Twierdzi też, że zmysły cielesnej natury nie są zdolne do poznania ciała niebieskiego (tò oủ@óvıv $\sigma \tilde{\omega} \mu \alpha)^{69}$. Możemy więc przypuszczać, że według Grzegorza, podobnie jak dla Orygenesa, wszystkie byty stworzone są w jakiś sposób cielesne, choć ciało niebieskic jest tak różne od ziemskiego, że Grzegorz nie waha się nazywać istot nim obdarzonych „bezcielesnymi"70. Dlatego możemy przypuszczać, że i „ludzka natura", powstała w wyniku pierwszego stworzenia, ów cielesny (choć nazywany bezcielesnym) aspekt posiada. Jak podkreśla J. Daniélou: „Fakt, że człowiek ma ciało zlożone z ziemskiej substancji i że to umożliwia mu życie na zicmi, wynika z zamysłu Stwórcy i harmonii świata [...]. Nie ma nic wspólnego $z$ grzechem" $" 71$.

$\mathrm{Z}$ pytaniem o cielesność związane jest inne: o stan Adama przed grzechem. Wszystkie cechy, które wiążemy $z$ obecną kondycją ludzi, a więc przede wszystkim śmiertelność i namiętności, Grzegorz nazywa zwierzęcym aspektem życia. Mówiąc o skutkach grzechu odwoluje się do obrazu odzienia ze skór z Rdz 3, 21, interpretując je w sposób alegoryczny. Do rozumnej i obdarzonej zyciem nadprzyrodzonym ludzkiej natury po grzechu zostały dodane właściwości natury nierozumnej ${ }^{72}$, których pozbędziemy się dopiero w czasie zmartwychwstania:

„Po zdjęciu brzydkiej, ze skór zwierzęcych sporządzonej śmiertelnej szaty (przez skórę zwierząt należy rozumieć znak nierozumnej natury, którą przywdzialiśmy oddając się namiętnościom), każdy kawałek okrywającej nas zwierzęcej skóry zdejmiemy wraz z całością. Tym zaś, cośmy wraz ze zwierzęcą skórą wzięli, jest parzenie się, poczęcie, rodzenie, brud, pierś macierzyńska, jedzenie, wypróżnianie, wzrost aż do dojrzałości, pełnia siły, starość, śmierć"

Wszystkie te aspekty życia stały się udziałem ludzi dopiero po pierwszym grzechu, zostały przydane ludzkiej naturze jako coś zewnętrznego i obcego, nie są integralnym elementem nie tylko pierwszego (co jest oczywiste), ale i drugiego stworzenia. Chociaż bowiem powstały w wyniku drugiego stworzenia Adam nie był już podobny do Boga, bo posiadał określoną płeć, nie doświadczał jednak jeszcze pozostałych przypadłości zwierzęcej natury.

R. Leys twierdzi, że - według Grzegorza - prarodzice żyli w raju w cialach duchowych, tworząc $z$ aniołami jeden chór rozumnych stworzeń i dopiero po

69 Por. In Ecclesiasten hom. VI, GNO 5, 374.

70 Por. Antirrheticus adversus Apollinarem, GNO 3/1, 212, gdzie Grzegorz nazywa równym

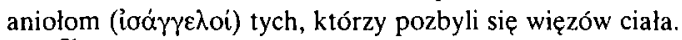

71 J. Daniélou, Les tuniques de peau chez Grégoire de Nysse, w: Glaube, Geist, Geschichte. Festschrift für Ernst Benz, Leiden 1967, 364.

72 J. Daniélou zauważa ( $L$ 'être et le temps chez Grégoire de Nysse, Leiden 1970, 154), że także Orygenes interpretowal ten fragment, przeciwstawiając cialo ziemskie eterycznemu, które będzie istniało po zmartwychwstaniu. Metody z Olimpu, przeciwnie, kladl nacisk na tożsamośc ciała zmartwychwstałego i cielesnego.

73 Dialogus de anima et resurrectione, PG 46, 148, PSP $14,82$. 
grzechu zostali obdarzeni ciałami zwierzęcymi oraz seksualnością ${ }^{74}$. H.U. von Balthasar wyróżnia aż cztery różne etapy stwarzania rodzaju ludzkicgo: ctap całkowicie idealny, kiedy ludzka natura miałaby się rozmnażać w sposób anielski, stworzenie „ludzkości” idealnej, ale nie mającej nic wspólnego z życiem w raju, następnie pierwszego realnego człowieka, mieszkającego w raju, i obdarzonego organami płciowymi, a więc i namiętnościami, ale bezgrzesznego oraz ostatni etap: grzech czlowieka i jego konsekwencje ${ }^{75}$. Najtrafniejszą wydaje mi się jednak interpretacja, jaką zaproponował F. Flori. Odróżnia on podział na płcie od popędu seksualnego i twierdzi, że Adam i Ewa, choć byli oczywiście obdarzeni płciowością, nie odczuwali jednak popędu seksualnego. Dodaje, że nie mogli oni rozmnazać się jak aniołowie, bo byli już podzieleni na płcie, byli już niejako przeznaczeni do rozmnażania zwierzęcego, choć miało siç ono dokonać dopiero po upadku ${ }^{76}$.

Grzegorz doprowadził naukę swoich poprzedników o podwójnym stworzeniu do doskonałości: tłumaczy bowiem powstanie świata zmystowego, pozostając wierny nauczaniu Kościoła i nie rezygnując przy tym z filozofii. Nowością w jego nauczaniu jest określenie jako przyczyny drugiego stworzenia nie tyle samego upadku, co Boskiego przewidywania owego upadku. Rozwiązało to, wydawałoby się nierozwiązywalny, problem powiązania powstania świata zmysłowego z upadkiem stworzeń rozumnych tak, by nie przesuwać owego upadku do preegzystencji ${ }^{77}$. Dzięki uznaniu, że człowiek indywidualny powstał ,dzięki Boskiej władzy przewidywania" Grzegorz mógł przypisać upadkowi człowieka wprowadzony uprzednio podział na płcie, a jednocześnie w zgodzie z przekazem biblijnym uznać, że sam upadek był wydarzeniem historycznym, dokonanym przez jednostkowego czlowieka, Adama.

\footnotetext{
${ }^{74}$ Por. R. Leys, L'image de Dieu chez Grégoire de Nysse, Paris 1951, 107.

${ }^{75}$ Por. H.U. von Balthasar, Présence et Pensée. Essai sur la philosophie religieuse de Grégoire de Nysse, Paris 1988, s. 52, przypis 5.

${ }_{76}$ Por. F. Flori, Le sens de la ,division des sexes" chez Grégoire de Nysse, RSR 27 (1953) 108-111.

77 Orygenes mógl jeszcze głosić taką tezę wierząc, że pozostaje wierny nauczaniu Kościoła, bo jak sam tłumaczy: „Nie określono [w nauce Kościoła] dosyć jasno, czy dusza bierze swój początek $\mathrm{z}$ posiewu nasienia - tak iż jej istota i substancja tkwią w owych cielesnych zarodkach - czy też ma inne pochodzenie: czy jest zrodzona, czy niezrodzona albo przynajmniej czy jest wprowadzana w ciało z zewnątrz, czy też nie" (De principiis I Praefatio, 5, SCh 252, 84, ŹMT 1, 54-55).
} 


\section{THE DUAL CREATION CONCEPT AS ATTEMPT TO EXPLAIN THE ORIGIN OF THE SENSUAL WORLD}

(Summary)

It seems there could be no connection of the biblical truth on the subject of creation with philosophy, which has never known the idea of creation. Nonetheless, several attempts have been made to unify them. The article presents three that are most renowned: of Philo, Origen and Gregory of Nyssa. They have one important feature in common: under the influence of Platonism, all three speak of dual creation. However, there are also some differences between their thoughts. Each of them sees different reality made in the first creation: Philo - the idea of humanity, Origen souls, Gregory of Nyssa - human nature. They differ also when speaking of the cause of the second creation. Philo seems to see the case in ontology: he asserts that some co-creators were the authors of evil and passion in man. Origen maintains that the second creation was connected to the sin of souls, committed in pre-cxistence. As a result of the fall souls received earthly bodies. Gregory also speaks of the effect of the fall, which was the cause of the second creation, but he thinks that the creation had been made in prevision of the fall. There is also small dissimilarity in treating the corporeity of the reality created in the first creation and the state of Adam before the original sin. 